\title{
Yerfıstığı Üretiminde Enerji Kullanım Etkinliğinin Belirlenmesi (Adana ili örneği)
}

\author{
Mehmet Fırat Baran ${ }^{1}$, Hasan Ali Karaağaç², Ali Bolat ${ }^{2}$, Abdullah Çil ${ }^{2}$, Ayşe Nuran Çil ${ }^{2}$ \\ ${ }^{1}$ Siirt Üniversitesi Ziraat Fakültesi Biyosistem Mühendisliği Bölümü, Siirt, Türkiye (ORCID: 0000-0002-7657-1227) \\ ${ }^{2}$ Doğu Akdeniz Tarımsal Araştırma Enstitüsü Müdürlüğü, Adana, Türkiye (ORCID: 0000-0003-4847-0426; 0000-0002-1019-0069; 0000-0001-8663-3260; \\ 000-0001-8520-6013)
}

(İlk Geliş Tarihi 24 Aralık 2018 ve Kabul Tarihi 26 Şubat 2019)

(DOI: $10.31590 /$ ejosat.501576)

ATIF/REFERENCE: Baran M.F, Karaağaç, H.A, Bolat, A, Çil A. \& Çil, A.N. (2018). Yerfıstığı Üretiminde Enerji Kullanım Etkinliğinin Belirlenmesi (Adana ili örneği). Avrupa Bilim ve Teknoloji Dergisi, (15), 103-111.

Öz

Bu çalışmada, 2017 yılında Adana koşullarında yetiştirilen yer fistığı üretiminin enerji bilançosu ortaya konulmuştur. Çalışmada kullanılan alet-makinelerin ekonomik ömürleri, iş başarısı, yakıt-yağ tüketimleri, makine ağırlıkları ile gübre, tohum miktarları gibi temel veriler, mevcuttaki yapılan ölçümlerden, yapılan diğer çalışmalardan, çeşitli kaynak ve kataloglardan temin edilmiştir. Yapılan değerlendirmeler sonucunda yer fistığı üretiminde enerji çıktı/girdi oranı 1.94, özgül enerji değeri $12.90 \mathrm{MJ} \mathrm{kg}^{-1}$, enerji üretkenliği 0.08 $\mathrm{kgMJ}^{-1}$, net enerji verimi 52734.28 MJ ha-1 olarak hesaplanmıştır. Yer fistığı üretiminde toplam enerji girdileri içerisinde kullanım oranı en yüksek olan \% 48.69 ile sulama enerjisi olduğu bulunmuştur. Bunu sırasıyla \% 22.31 ile yakıt-yağ enerjisi, \% 14.90 ile gübre enerjisi, $\% 5.78$ ile tohum enerjisi, \% 5.58 ile ilaç enerjisi, \% 2.59 ile makine enerjisi ve \% 0.16 ile insan enerjisi takip etmiştir.

Anahtar Kelimeler: Adana, yerfıstığı, enerji oranı, enerji etkinliği

\section{Determining Energy Usage Efficiency in Groundnut Production (The case of Adana Province)}

\begin{abstract}
In this study, energy balance in grown groundnut was revealed in Adana. Main data used in this study, such as economical life, labor success, fuel-oil consumptions, machine weights of the tools and machines used in second crop sunflower and fertilizer, irrigation, seed amounts have been obtained from the other studies, various sources and catalogues. As a result of the evaluations energy output/input rate was obtained as 1.94 , the specific energy value was obtained 12.90 , net energy production was obtained $52734.28 \mathrm{MJ} /$ ha in groundnut. For the groundnut, irrigation energy was the highest energy with 48.69 in total energy budget followed by fuel-oil energy, fertilizer energy, seed energy, chemicals energy, machinery energy and human labour energy inputs with $22.31 \%, 14.90,5.78 \%, 5.58 \%$ , $2.59 \%$ and $0.16 \% \%$ respectively.
\end{abstract}

Keywords: Adana, groundnut, energy rate, energy efficiency

*Sorumlu Yazar: Siirt Üniversitesi, Ziraat Fakültesi, Biyosistem Mühendisliği Bölümü, Siirt, Türkiye, ORCID: 0000-0002-7657-1227, $\underline{\text { mfb197272@gmail.com }}$ 


\section{Giriş}

Tek yıllık ve yazlık olarak yetiştirilen ve sıcak bir iklim bitkisi olan yerfıstığı, baklagiller familyasından olup, tanelerindeki yüksek yağ içeriğinden dolayı yağlı tohumlu bitkiler grubuna dahil edilir (Anonim, 2018a).

Yer fistığı tohumlarında ortalama \% 45-55 oranında yăg (Boydak ve Kara, 2015), \% 20-30 oranında protein, \% 15-20 oranında karbonhidrat olmak üzere çeşitli vitamin ve mineral maddeler bulunmaktadır. Yer fistığının yağı çıkarıldıktan sonra bile geriye kalan küspesinde dahi yaklaşık \% 40-45 oranında ham protein bulunmaktadır. Bu nedenle yerfistığ1 tohumları içerdiği yă̆, protein, karbonhidrat, vitaminler ve madensel maddeler ile insanlar ve hayvanların değerli bir besin kaynağıdır (Anonim, 2018b). Bir baklagil bitkisi olması nedeniyle, havanın serbest azotundan faydalandığı için kendisinden sonra ekilecek bitkiye azot ve organik maddece zengin bir toprak bırakan yerfıstığı, çapa bitkisi olması nedeniyle de yetişme süresi boyunca devamlı çapalandığı için yabancı otlardan temizlenmiş ve havalanmış bir toprak bıraktığından dolayı iyi bir ekim nöbeti bitkisidir. Ülkemizin bazı yerlerinde ana ürün olarak yetiştirilebildiği gibi hububattan sonra ikinci ürün olarak da yetiştirilebilir. (Anonim, 2018a). Adana'da üretimi yapılan yerfıstığı üretim miktarları Tablo 1 'de verilmiştir.

Tablo 1. Yıllar itibarı ile Adana yerfistı̆̆ üretim miktarları

\begin{tabular}{|l|c|c|c|}
\hline \multirow{2}{*}{ Y1llar } & \multicolumn{3}{|c|}{ Yer fist $\breve{g ̆}_{1}$} \\
\cline { 2 - 4 } & & Üretim (Ton) & Verim (kg/da) \\
\hline 2013 & Alan (da) & 46770 & 401 \\
\hline 2014 & 116654 & 50448 & 411 \\
\hline 2015 & 122880 & 65915 & 450 \\
\hline 2016 & 146480 & 71571 & 437 \\
\hline 2017 & 163860 & 68094 & 436 \\
\hline
\end{tabular}

Kaynak: TÜik (Anonim, 2018c)

Türkiye'de yerfıstığı ekim alanının \%79'u ve üretimin \%81'i Adana ve Osmaniye'de gerçekleşmektedir. Adana 3.8 ton/ha ile en yüksek verime sahip olan ildir. Bu ili 3.4 ton/ha ile Osmaniye izlemektedir (Aşık v.dğr, 2018). Tarımsal üretimle ilgili olarak yapılacak enerji analizleri tarımsal sistemlerin enerji tüketimi açısından tanımlanıp gruplandırılmasında önemli bir yaklaşımdır. Üretiminde verimi artırmak ve girdileri azaltmak için üretimde kullanılan girdi ve çıktıların dikkatli bir şekilde analiz edilmesi gereklidir (Sabah, 2010).

Enerji etkinliği değerini artırmak için ya verimin artırılması ya da girdilerin azaltılması gerekmektedir. Özellikle toplam enerji girdisi içerisinde büyük yer tutan yakıt, kimyasal gübreler, tarımsal ilaçlar, makine ve traktör girdilerinin azaltılması gerekmektedir. Verimin artırılması belirli sınırlar içerisinde sağlanabilir. Fakat enerji kullanım etkinlik değeri girdilerin bilinçli bir şekilde yapılmasıyla (ilaçlama, mekanizasyon ve gübreleme) azaltılabilir (Çelen 2016).

Enerji kullanım etkinliğini belirlemek amacıyla yapılan bazı çalışmalarda, lavanta (Gökdoğan 2016), arpa (Baran ve Gökdoğan 2014), ikinci ürün ayçiçeği (Baran v.dğr 2016), şekerpancarı (Baran ve Gökdoğan, 2016), ceviz (Banaeian, v.dğr, 2010; Khoshroo ve Mulwa, 2014; Baran v.dğr 2017), fistık (Nabavi-Pelesaraei v.dğr, 2013; Azarpour v.dğr 2012), yer fistığ1 ( Singh ve ark, 1997; Umar, 2003; Firouzi ve Aminpanah.2012; Kumar v.dğr, 2015), badem, (Marvinney v.dğr, 2015; Beigi v.dğr 2016; Baran v.dğr 2018), üretiminde enerji kullanım etkinlikleri belirlenmiştir. Bu çalışmada Adana'da 2017 yılı yer fistığı üretiminin enerji bilançosu ortaya konmaya çalışılmıştır.

\section{Materyal ve Metot}

\section{1. Çalıșma alanı}

Akdeniz iklimi görülen Adana ilinde uzun yıllar yılık yağış miktarı ortalama $644.6 \mathrm{~mm}$, ortalama sıcaklık ise yaklaşık $19.1{ }^{\circ} \mathrm{C}$ civarındadır (Anonim, 2018d). Çalışmada yerfıstığı üretiminde kullanılan çeşitli girdi miktarları ve elde edilen çıktı miktarları değerleri değişik kaynaklardan (Türkiye İstatistik Kurumu, daha önce konuyla ilgili veya benzer çalışmalardan), tarım alet ve makinaların teknik verileri ise bölgedeki uygulamalardan ve kataloglardan alınmıştır. Adana'da yerfıstığı üretimi için yapılan kültürel uygulamalar ve bakım işlemleri Tablo 2'de belirtilmiştir. 
Tablo 2. Yerfıstığı Üretimi İçin Kültürel Uygulamalar ve Bakım İşlemleri

\begin{tabular}{|c|c|}
\hline Kültürel Uygulamalar & Uygulamanın Özelliği \\
\hline Toprak işleme & $\begin{array}{l}\text { Toprak, sonbaharda pulluk ile } 20-25 \mathrm{~cm} \text { derinlikte sürülür. Toprak kışın } \\
\text { kültivatör ile tekrar sürülür. Daha sonra nisan ayında goble / diskaro ile } \\
\text { işleme yapılır. En son olarak toprağın nem durumuna göre } 2-3 \text { kez merdane } \\
\text { veya tapan ile toprak düzeltilir / bastırılır. }\end{array}$ \\
\hline Ekim & $\begin{array}{l}\text { Nisan ayının ortalarından itibaren toprak pnömatik ekim makinası ile sıra } \\
\text { arası } 70 \mathrm{~cm} \text {, sıra üzeri ortalama } 10-13 \mathrm{~cm} \text { olacak şekilde ekim yapı1lır. } \\
\text { Kullanılacak olan tohum miktarı, tohum büyüklüğune bağlı olarak 10-18 } \\
\mathrm{kg} / \mathrm{da} \text { arasında olmaktadır. Yerfıstığı tohumları, ekilmeden önce toprak altı } \\
\text { hastalık ve zararlısına karşı ilaçlanmalıdır. }\end{array}$ \\
\hline Gübreleme & $\begin{array}{l}\text { Ekimle birlikte } 8-10 \mathrm{~kg} / \mathrm{da} \text { saf fosfor, yaklaşı } 3 \mathrm{~kg} / \mathrm{da} \text { saf azot verilmelidir. } \\
\text { Ekimle birlikte verilen azot miktarına ek olarak yaklaşı } 10-15 \mathrm{~kg} / \mathrm{da} \text { saf } \\
\text { azot amonyum sülfat formunda } 1 \text {. yağmurlama sulamanın öncesinde } \\
\text { verilir. Bazı topraklarda demir eksikliği ihtiyacı olmas durumunda } \\
\text { yapraktan demir uygulaması yapılır. }\end{array}$ \\
\hline Ara çapa & $\begin{array}{l}\text { Yer fistığı yetiştirilmesi süresince toplam } 4-5 \text { defa traktör ara çapa ile } \\
\text { çapalanır. Toprağın durumuna göre boğaz doldurma yapılması gerekebilir. }\end{array}$ \\
\hline Yabanc1 Ot Mücadelesi & $\begin{array}{l}\text { Mücadelede genellikle el çapası yerine çıkış sonrası yabancı ot durumuna } \\
\text { göre } 1 \text { veya } 2 \text { uygulama olmak üzere herbisit kullanılmaktadır. }\end{array}$ \\
\hline Zirai Mücadele & $\begin{array}{l}\text { Yer fistığı üretiminde havanın ve çevrenin durumuna bağlı olarak 3-4 defa } \\
\text { yaprak biti, kırmızı örümcek ve fungusit ilaçlaması yapılmaktadır. }\end{array}$ \\
\hline Sulama & $\begin{array}{l}\text { Adana'da yerfıstığı bitkisinin büyük çoğunluğu yağmurlama sulama } \\
\text { şeklinde sulanmaktadır. Yer fistığı bitkisi, yetişme döneminde iklim ve } \\
\text { toprak şartlarına da bağlı olmak üzere ortalama } 5 \text { kez sulanır. Hava } \\
\text { sıcaklığının fazla veya kumlu toprak olması durumunda sulama sayısı } \\
\text { arttırılır. }\end{array}$ \\
\hline Hasat & $\begin{array}{l}\text { Yer fistığında hasat zamanı artık bitkilerin yapraklarının sararmaya } \\
\text { başlandığı, tanelerin pembe renk aldığı veya kabuk iç kısmının beyazdan } \\
\text { kahverengiye döndü̆g̈u ve kapsüllerin dolduğu devredir. Yer fistığ } 1 \\
\text { bitkileri, } 2 \text { veya } 3 \text { sırası } 1 \text { sıra namlu olacak şekilde yerfıstığ sökme } \\
\text { makinası ile topraktan sökülür ve ters çevrilir. } 3-5 \text { gün güneşte böyle } \\
\text { kaldıktan sonra toplama ve harmanlama makinası ile toplanır. Toplanan } \\
\text { ürünler sergen yerine taşınır ve son olarak eleme işlemine tabi tutulur. }\end{array}$ \\
\hline
\end{tabular}

\section{2 Çalışmada Kullanılan Girdiler}

Ekim normu sıra üstü arasına ve tohum büyüklüğüne bağlı olarak $10-18 \mathrm{~kg} / \mathrm{da}$ arasında değişmekte olup bu çalışmada ekim normu $13 \mathrm{~kg} / \mathrm{da}$ olarak alınmıştır. Ekim işleminden önce her $100 \mathrm{~kg}$ tohum, toprak altı hastalık ve zararlısına karşı ve kullanılan ilacın çeşidine göre ortalama $0.15 \mathrm{~kg}$ insektisit ve $0.5 \mathrm{~kg}$ fungusit ile ilaçlanmaktadır. Kullanılan gübre miktarı $10 \mathrm{~kg} / \mathrm{da}$ saf fosfor ve $12 \mathrm{~kg} / \mathrm{da}$ saf azot olarak hesaplanmıştır. Yer fıstığı yabancı ot mücadelesi için çıkış sonrası 2 herbisit uygulaması, çeşitli hastalık ve zararlılar için 3 defa fungusit ve insektisit uygulaması yapılmıştır. Yağmurlama sulama yer fistığında 5 defa olarak hesaplanmıştır. Bölgede yer fistığı bitkisinin ortalama su tüketimi $652.3 \mathrm{~mm} / \mathrm{da}$ (Anonim, 2018e) civarındadır. Yer fistığı üretiminde toprak işlemede 1 sürücü, ekim ve gübreleme işleminde 1 sürücü ve 1 yardımcı, yağmurlama sulama işlemleri boyunca ise 4 işci çalışmıştır. Adana'da yer fistığı üretiminin enerji etkinliğinin hesaplanabilmesi için öncelikle enerji girdilerinin ve enerji çıktılarının hesaplanması gerekir. Enerji girdileri insan gücü enerjisi, makine enerjisi, yakıt-yağ enerjisi, tohum enerjisi, su enerjisi, gübre enerjisi ve ilaç enerjisinden oluşmaktadır. Enerji çıktısı ise birim alandan elde edilen ürün ve yan üründen oluşmaktadır.

Adana ilinde yer fistığı için yapılan ölçümlere göre, enerji girdilerinin ve çıktılarının değerleri belirlenmiştir. Enerji girdileri olarak traktör yapım enerjisi (Traktör için makine yapım enerjisi Türkiye için $35.216 \mathrm{MJ} \mathrm{kg}^{-1}$ olarak hesaplanmıştır (Acaroğlu 1998). Makine yapım enerjisi, yakıt-yağ enerjisi, gübre enerjisi, tarımsal ilaç enerjisi, insan işgücü enerjisi, tohum enerjisi ve taşıma enerjisi değerleri 
ele alınmıştır. İkinci ürün yer fıstığı üretiminde enerji kullanım analizini belirlemek amacıyla, enerji oranı, spesifik enerji, enerji verimliliği ve net enerji verimi 1, 2, 3 ve 4 numaralı formüllerde (Yılmaz v.dğr, 2010) kullanılmıştır.

Enerji oran $=\frac{\text { Enerji çıtısı }}{\text { Enerji girdisi }}$

1 no'lu eşitlikte enerji çıktısı ve enerji girdisi MJ/ha olarak verilmiştir.

Spesifik enerji $=\frac{\text { Enerji girdisi }}{\text { Ürün verimi }}$

Enerji verimliliği $=\frac{\text { Üretim miktarı }}{\text { Enerji girdisi }}$

2 ve 3 no’lu eşitlikte ürün verimi birimi MJ/ha olarak kullanılmıştır.

Net enerji verimi $=$ Enerji çıktısı - Enerji girdisi

Tarımsal üretimde kullanılan girdi ve çıktıların enerji eşdeğerleri Çizelge 3’te verilmiştir. Enerji çıktısı ise birim alandan elde edilen ürün ve yan üründen oluşmaktadır. Enerji girdisinin ve enerji çıktısının hesaplanmasında girdi ve çıktı çeşitlerinin enerji eş değerlerinin bilinmesi gerekir. Enerji eşdeğerlerinin belirlenmesinde daha önce yapılan araştırmalardan faydalanılmıştır. Bu kaynaklar Tablo 3 'te gösterilmiştir.

Tablo 3. Tarımsal üretimde girdi ve çıktıların enerji eşdeğerleri

\begin{tabular}{|c|c|c|}
\hline Girdiler & $\begin{array}{l}\text { Enerji Eşdeğeri } \\
\text { Katsayısı(MJ/birim) }\end{array}$ & Referanslar \\
\hline İnsan İsgü̈cü $(h)$ & 1.96 & $\begin{array}{l}\text { Davoodi ve Houshyar, 2009; Mousavi Avval } \\
\text { v.dğr, } 2011\end{array}$ \\
\hline \multicolumn{3}{|c|}{ Makine Üretim Enerjisi (kg) } \\
\hline Traktör & 158.3 & Barut v.dğr, 2011 \\
\hline Toprak İşleme Aletleri & 121.3 & Barut v.dğr, 2011 \\
\hline \multicolumn{3}{|l|}{ Yakat (L) } \\
\hline Dizel & 35.69 & Eren, 2011 \\
\hline Yağ & 6.51 & Eren, 2011 \\
\hline \multicolumn{3}{|l|}{ Kimyasal Gübreler (kg) } \\
\hline Azot $(\mathrm{N})$ & 60.6 & Öztürk, 2011; Barut v.dğr, 2011; Bayhan, 2016 \\
\hline Fosfor $\left(\mathrm{P}_{2} \mathrm{O}_{5}\right)$ & 11.1 & Öztürk, 2011, Bayhan, 2016 \\
\hline \multicolumn{3}{|l|}{$\dot{I} l a c ̧(k g)$} \\
\hline Herbisit & 269 & $\begin{array}{l}\text { Ferrago, 2003; Sabah, 2010; Arıkan, 2011, Eren, } \\
2011\end{array}$ \\
\hline İnsektisit & 214 & Sabah, 2010, Arıkan, 2011, Eren, 2011 \\
\hline
\end{tabular}


European Journal of Science and Technology

\begin{tabular}{|l|l|l|}
\hline Fungusit & 278 & Firouzi ve Aminpanah, 2012 \\
\hline Tohum $(\mathrm{kg})$ & & \\
\hline Yerfistığ1 & 25 & Ghosh, v.dğr, 2006; Kumar v.dğr, 2015 \\
\hline Sulama & 4.2 & Eren 2011; Mrini v.dğr 2002 \\
\hline Çıtı & & \\
\hline Yerfistığ1 & 25 & Ghosh, v.dğr, 2006; Kumar v.dğr, 2015 \\
\hline
\end{tabular}

Ayrıca yerfıstığı üretimindeki enerji girdileri, doğrudan ve dolaylı enerji girdileri olarak iki grupta hesaplanmıştır. Yerfıstığı üretiminde tarım alet ve makinaları tarafından tüketilen yakıt ve yağ enerji değeri doğrudan enerji girdisi olarak, yerfıstığı üretiminde kullanılan insan işgücü, tarım alet ve makinaları, gübre, ilaç ve tohumluk için tüketilen enerji değerleri dolaylı enerji girdisi olarak dikkate alınmıştır.

\section{Araştırma Sonuçları ve Tartışma}

\subsection{Araştırma sonuçları}

Adana'da yer fistığı üretiminde enerji bilançosu Tablo 4'te, verilmiştir. Tablo 4'ü incelediğimizde birim alan başına $89.52 \mathrm{MJ} / \mathrm{ha}$ insan enerjisi tüketilmiş, bu değer \% 0.16 ile en düşük girdiyi oluşturmuştur. Yer fistığı üretiminde alet/makine enerjisinde 1 ha alan için $1454.95 \mathrm{MJ}$ enerji tüketilmiş, bu değer toplam enerji içerisinde \% 2.59 oranına karşılık gelmiştir. Tüm girdiler içerisinde sulama enerjisi $27396.60 \mathrm{MJ} /$ ha tüketilerek \% 48.69 oranı ile en yüksek sırada olmuştur. Yakıt-yağ enerji girdisi $12550.85 \mathrm{MJ} / \mathrm{ha}$ tüketilerek \% 22.31, gübre enerji girdisi $8382.00 \mathrm{MJ} / \mathrm{ha}$ ile $\% 14.90$ oranlarına karşılık gelmiştir. Yer fistığ üretiminde ilaç enerji girdisi ise 3141.80 $\mathrm{MJ} /$ ha ile $\% 5.58$ oranına sahipken, tohum enerji girdisi $3250 \mathrm{MJ} /$ ha değeri ile $\% 5.78$ oranına sahip olmuştur.

Tablo 4. Adana'da Yer fistı̆̆ Üretiminde Enerji Bilançosu

\begin{tabular}{|c|c|c|c|}
\hline \multicolumn{1}{|l|}{ Girdi } & $\begin{array}{c}\text { Hektar Başına } \\
\text { Miktar }\end{array}$ & $\begin{array}{c}\text { Toplam Enerji Girdisi } \\
\text { (MJ/ha) }\end{array}$ & $\begin{array}{c}\text { Toplam Enerji } \\
\text { Girdisine } \\
\text { Oranı }\end{array}$ \\
\hline İnsan Işsücü (h) & 45.67 & 89.52 & 0.16 \\
\hline Toprak Hazırlama İşlemleri & 5.47 & 10.71 & \\
\hline Ekim ve Diğer İşlemler & 29.87 & 58.55 & \\
\hline Hasat & 10.33 & 20.25 & \\
\hline Makine (h) & 43.35 & 1454.95 & \\
\hline Traktör & 21.67 & 366.83 & \\
\hline Toprak Hazırlama İşlemleri & 5.47 & 106.06 & \\
\hline Ekim ve Diğer İşlemler & 12.54 & 221.91 & \\
\hline Hasat & 3.67 & 760.15 & \\
\hline Yakıt + Yağ (L) & 364.50 & 12550.85 & \\
\hline Toprak Hazırlama İşlemleri & 75.24 & 2590.77 & \\
\hline Ekim ve Diğer İşlemler & 226.56 & 7801.10 & \\
\hline Hasat & 62.70 & 2158.98 & \\
\hline
\end{tabular}


Avrupa Bilim ve Teknoloji Dergisi

\begin{tabular}{|c|c|c|c|} 
Kimyasal Gübreler (kg) & 220.00 & 8382.00 & 14.90 \\
\hline Fosfor (P) & 100.00 & 1110.00 & \\
\hline Azot (N) & 120.00 & 7272.00 & \\
\hline Kimyasallar (kg) & 12.05 & 3141.80 & 5.58 \\
\hline Herbisit & 2.50 & 672.50 & \\
\hline Fungusit & 6.65 & 1848.70 & \\
\hline İnsektisit & 2.90 & 620.60 & 5.78 \\
\hline Tohum (kg) & 130.00 & 3250.00 & 48.69 \\
\hline Sulama (m $\left.{ }^{3}\right)$ & 6523.00 & 27396.60 & \\
Toplam Enerji Girdisi & & 56265.72 & \\
\hline
\end{tabular}

Tablo 5. Yer Fistığı yetiştiriciliğinde genel enerji girdileri ve dağgllımlarl

\begin{tabular}{|c|c|c|}
\hline Enerji girdileri & $\mathrm{MJ} \mathrm{ha}^{-1}$ & Dağılım (\%) \\
\hline Yakıt-yağ enerjisi & 12550.85 & 22.31 \\
\hline Makine enerjisi & 1454.95 & 2.59 \\
\hline İnsan İşgücü enerjisi & 89.52 & 0.16 \\
\hline Tohum enerjisi & 3250.00 & 5.78 \\
\hline Tarımsal ilaç/ Kimyasallar & 3141.80 & 5.58 \\
\hline Gübre enerjisi & 8382.00 & 48.90 \\
\hline Sulama enerjisi & 27396.60 & 100.00 \\
\hline Toplam & 56265.72 & 48.69 \\
\hline
\end{tabular}

Tablo 6. Yer Fıstı̆̆ yetiştiriciliğinde toplam enerji girdi-çıktı ve enerji oranı değerleri

\begin{tabular}{|l|c|c|}
\hline Toplam Enerji Girdisi (MJ/ha) & & 56265.72 \\
\hline Verim & 4360 & 109000.00 \\
\hline Toplam Enerji Çıktısı (MJ/ha) & & 109000.00 \\
\hline Enerji Oranı & & 1.94 \\
\hline Özgül Enerji (MJ/kg) & & 12.90 \\
\hline Enerji Üretkenliği (kg/MJ) & & 0.08 \\
\hline Net Enerji Verimi (MJ) & & 52734.28 \\
\hline
\end{tabular}

Tablo 6'da görüldüğ̈̈ gibi yer fistı̆̆ı üretiminden elde edilen toplam enerji girdisi $56265.72 \mathrm{MJ} / \mathrm{ha}$, toplam enerji çıktısı 109000,00 MJ/ha, enerji oran 1.94 olarak saptanmıştır. Yapılan bu çalışmada saptanan enerji oranı 1.94 iken, Firouzi ve Aminpanah. (2012) İran kuzeyindeki Kiashahr bölgesinde yer fistı̆ın üretiminde enerji oranı'nı 3.93, Azarpour v.dğr ( 2012) İran'ın kuzeyindeki Guilan bölgesinde fistık üretiminde enerji oranını 2.73, Nabavi-Pelesaraei v.dğr (2012), İran'ın kuzeyindeki Guilan bölgesindeki üç farklı 
şehirdeki 120 fistık üretimi yapan işletmelerdeki enerji oranını 4.53 olarak tespit etmişlerdir. Adana koşullarında yer fistığ üretiminde enerji üretkenliği, sadece birim üretim alanından (ha) alınan tohum miktarı dikkate alındığında $0.08 \mathrm{~kg} / \mathrm{MJ}$ olarak belirlenmiştir. Adana koşullarında yer fistığı üretiminde, $1 \mathrm{MJ}$ enerji tüketimi karşılığında $0.08 \mathrm{~kg}$ yer fistığı tohumu üretilmektedir. Yer fistığı üretiminde bu değer; Firouzi ve Aminpanah. (2012) İran'ın kuzeyindeki Kiashahr bölgesinde yapmış oldukları çalışmalarında 0.212 kg/MJ, Fıstık üretiminde ise bu değer; Nabavi-Pelesaraei v.dğr ( 2012) tarafından İran'da yapılan çalışmada 0.18 kg/MJ, Azarpour v.dğr ( 2012) İran'ın kuzeyindeki Guilan bölgesinde yaptıkları çalışmada 0.14 kg/MJ olarak belirlemişlerdir. Üretim sonucunda kazanılan toplam enerji miktarı ile üretim işlemlerinde kullanılan toplam enerji miktarı arasındaki fark net enerji verimi (MJ/ha) olarak tanımlanır (Baran v.dğr 2014). Adana koşullarında yer fıstığı üretiminde net enerji verimi, sadece birim üretim alanından (ha) alınan tohum miktarı dikkate alındığında 52734.28 MJ/ha, olarak belirlenmiştir. Yer fistığı üretiminde bu değer; Firouzi ve Aminpanah. (2012) İran kuzeyindeki Kiashahr bölgesinde yapmış oldukları çalışmalarında 59087.66 MJ/ha, Fıstık üretiminde ise bu değer; Nabavi-Pelesaraei v.dğr (2012) tarafından İran'da yapılan çalışmada 67937.21 MJ/ha, Azarpour v.dğr (2012) İran kuzeyindeki Guilan bölgesinde yaptıkları çalışmada $58926 \mathrm{MJ} /$ ha olarak tespit etmişlerdir.

Yer fıstığı yetiştiriciliğinde doğrudan, dolaylı, yenilenebilir ve yenilenemez enerji oranları sırasıyla \%71.16, \%28.84, \%54.63 ve \%45.37 olarak hesaplanmıştır (Tablo7). Firouzi ve Aminpanah (2012) tarafından yapılan yerfistığı çalışmasında da dolaylı enerji doğrudan enerjiden fazla, yenilenebilir enerji yenilenemez enerjiden yüksek, Nabavi-Pelesaraei v.dğr (2013) tarafindan yapılan yer fıstığı çalışmasında ise dolaylı enerji doğrudan enerjiden düşük, yenilenemez enerji yenilenebilir enerjiden yüksek bulunmuştur.

Tablo 7. Yer Fıstı̆̆ yetiştiriciliğinde doğrudan, dolayl, yenilenebilir ve yenilenemez enerji girdileri

\begin{tabular}{|c|c|c|}
\hline Yer Fistığ & Enerji girdisi (MJ ha-1) & Oran $(\%)$ \\
\hline Doğrudan enerji ${ }^{\text {a }}$ & 40036.97 & 71.16 \\
\hline Dolaylı enerji $^{b}$ & 16228.75 & 28.84 \\
\hline Toplam & 56265.72 & 100.00 \\
\hline Yenilenebilir enerji $^{c}$ & 30736.12 & 54.63 \\
\hline Yenilenemez enerji ${ }^{\mathrm{d}}$ & 25529.60 & 45.37 \\
\hline Toplam & 56265.72 & 100.00 \\
\hline
\end{tabular}

\section{Sonuç ve öneriler}

$\mathrm{Bu}$ araştırmada, Adana ilinde 2017 yılı üretim sezonunda yer fistığı üretiminde enerji kullanım etkinliğinin belirlenmiştir. Hesaplamalar sonucunda, üretim girdileri içerisinde en yüksek payı sulama enerjisinin aldı̆̆ı, bunu sırasıyla yağ-yakıt, gübre, tohum, ilaç, makine ve insan iş gücü enerjilerinin izlediği görülmektedir. Sulama enerji girdisinin azaltılması için bitkinin ihtiyacı kadar suyun zamanında ve gereği kadar verilmesi gerekmektedir. Adana'da yer fıstığı tarımında enerji çıktı/girdi oranı göz önüne alındığında verimli bir üretim yapıldığı söylenebilir. 


\section{Kaynakça}

Acaroğlu, M, 1998. Energy from biomass and applications. University of Selcuk Graduate of Natural and Applied Sciences, Textbook, Konya

Anonim,2018a.https://arastirma.tarim.gov.tr/batem/Belgeler/Kutuphane/Teknik\%20Bilgiler/yerfistigi\%20yetistiriciligi.pdf. Adresinden alınd, Erişim tarihi: 26.06.2018

Anonim, 2018b. http://www.gencziraat.com/Tarla-Bitkileri/Yerfistigi-Tarimi.html. Adresinden alındı, Erişim tarihi: 26.06 .2018

Anonim, 2018c. https://biruni.tuik.gov.tr/medas/?kn=92\&locale=tr, Adresinden alındı, Erişim tarihi: 03.07.2018

Anonim,2018d.https://www.mgm.gov.tr/veridegerlendirme/il-ve-ilceler istatistik.aspx?m=Adana, Adresinden alınd1 Erişim tarihi: 11.07 .2018

Anonim, 2018e.TAGEM ve DSİ, 2016. Türkiye'de Sulanan Bitkilerin Bitki Su Tüketimi Rehberi.Tarımsal Araştırmalar ve Politikalar

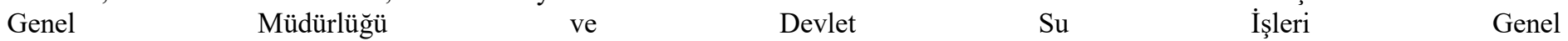
Müdürlüğü.https://www.tarim.gov.tr/TAGEM/Belgeler/T\%C3\%BCrkiyede\%20Sulanan\%20Bitkilerin

\%20Su\%20T\%C3\%BCketimi\%20Rehberi\%205-9-2016.pdf. Adresinden alındı, Erişim Tarihi: 18.09.2018

Aşık, F.F, Yıldız, R., Arıoğlu, H.H, 2018 Osmaniye Koşullarına Uygun Yeni Yerfıstığı Çeşitleri İle Bunların Önemli Tarımsal ve Kalite Özelliklerinin Belirlenmesi, KSÜ Tarım ve Doğa Dergisi, 21(6):825-836, 2018

Azarpour, E, Maral Moraditochaee, M. ve Bozorgi H.R., 2012, Evaluation energy balance and energy indices of peanut production in north of Iran, African Journal of Agricultural Research Vol. 7(16), pp. 2569-2574, 26 April, 2012 Available online at http://www.academicjournals.org/AJAR DOI: 10.5897/AJAR11.1897 ISSN 1991-637X @2012 Academic Journals

Arıkan, M., 2011. Adana Illinde Kolza Üretiminde Enerji Kullanımı. Çukurova Üniversitesi Fen Bilimleri Enstitüsü Tarım Makinaları Anabilim Dalı. Yüksek Lisans Tezi.

Baran, M.F., Gökdoğan, O., Karaağaç, H.A., 2014. Kanola Üretiminde Enerji kullanım Etkinliğinin Belirlenmesi (Kırklareli İli Örneği). Türk Tarım ve Doğa Bilimleri Dergisi 1(3): s: 331-337, 2014

Baran, M.F. and O.Gökdoğan, 2014. Energy input-output analysis of barley production in Thrace region of Turkey. American-Eurasian J. Agric. \& Environ. Sci. 14(11):1255-1261

Baran, M.F., R.Polat and O.Gökdoğan, 2016. Comparison of energy use efficiency of different tillage methods on the secondary crop sunflower production. Fresenius Environmental Bulletin, 25(11):4937-4943

Baran, M.F., Gökdoğan, O, 2016, Determination Of Energy Balance of Sugar BeetProduction in Turkey: A Case Study For Kirklareli Province, Springer Energy Efficiency (2015) 9: (2) 487-494, ISSN: 1570-6478; DOI 10.1007/s12053-015-9375-x

Baran, M.F, Gökdoğan, O, Oğuz, H.İ, 2017. Determining The Energy Usage Efficiency of Walnut (Juglans Regia L.) Cultivation in Turkey, Springer, Erwerbs-Obstbau, ISSN: 0014-0309, Volume 59, pp77-82, DOI 10.1007/s10341-y

Baran, M.F, Eren, Ö, Gökdogan,O, Oğuz, H.İ., 2018 Determination of Energy Efficiency and Greenhouse Gas (GHG) Emission in Organic Almond Production in Turkey, Abstract book, Volume: 1, Page : 105, XIX. World Congress of CIGR (the International Commission of Agricultural and Biosystems Engineering) Antalya, Turkey, (CIGR-April 22-25, 2018)

Barut, Z.B., C., Ertekin, H.A., Karaağaç, 2011. Tillage Effects on Energy Use for Corn Silage in Mediterranean Coastal of Turkey. Magazine of Energy. Volume 36, Issue 9, s: 5466-5475

Banaeian, N, Morteza, Z, Omid, M., 2010, Energy Use Efficiency for Walnut Producers Using Data Envelopment Analysis (DEA), Australian Journal of Crop Science, Vol. 4, No. 5, 2010: 359-362

Bayhan, Y., 2016. İkinci Ürün Ayçiçeği Üretiminde Farklı Toprak İşleme ve Doğrudan Ekim Yöntemlerinin Enerji Kullanım Etkinliğinin Karşılaştırılmasi. Tekirdă Ziraat Fakültesi Dergisi. 2016: 13 (02) 102

Beigi, M., Torki-Harchegani, M. \& Ghanbarian, D. 2016, Energy use efficiency and economical analysis of almond production: a case study in Chaharmahal-Va-Bakhtiari province, Iran, Energy Efficiency (2016) 9: 745. https://doi.org/10.1007/s12053-015-9395-6

Boydak, Ç., Kara, O., 2015. Yer Fıstığında Toprak İşleme Yöntemlerinin Yakıt Tüketimi, Tarla Filiz Çıkış Oranı Ve Toprağın Bazı Fiziksel Özelliklerine Etkisi. Tarım makinaları bilim dergisi (Journal of agricultural Machinery Science) 2015, 11 (2), 121-127 
Çelen, İ.H. 2016, Tarımsal uygulamalarda enerji kullanımı üzerine bir değerlendirme, Electronic Journal of Vocational Colleges- S: 1829 Aralık 2016

Davoodi, M. J. S.., Housyar, E. 2009. Energy consumption of canola and sunflower production in Iran. American-Eurasian J. Agric. \& Environ. Sci., 6(4): 381-384. ISSN 1818-6769, IDOSI Publications.

Eren, Ö., 2011. Çukurova Bölgesinde Tatlı Sorgum (Sorghum Bıcolor (L.) Moench) üretiminde Yaşam Döngüsü Enerji ve Çevresel Etki Analizi. Çukurova Üniversitesi Fen Bilimleri Enstitüsü Tarım Makinaları Ana Bilim Dalı Doktora Tezi. Adana 2011.

Ferrago, D. O., 2003. Energy Cost/Use in Pesticide Production. Encyclopedia of Pest Management.,

Firouzi S., ve Aminpanah, H.,2012 Energy Use Efficiency for Groundnut (Arachis hypogaea L.) Production in a Semi-mechanized Cultivation System, Scholars Research Library, Annals of Biological Research, 2012, 3 (8):3994-3997

Göokdoğan,O, 2016, Determination of input-output energy and economic analysis of lavender production in Turkey, Int J Agric \& Biol Eng, IJABE, May, 2016 9(3): 154-161

Ghosh, P. K., Mohanty, M., Bandyopadhyay, K. K., Painuli, D. K. and Misra, A. K., Growth, competition, yield advantage and economics in soybean/pigeonpea intercropping system in semi-arid tropics of India: I. Effect of sub soiling. Field Crops Res., 2006, 96(1), 80-89.

Khoshroo A., Mulwa R. (2014) Improving Energy Efficiency Using Data Envelopment Analysis: A Case of Walnut Production. In: Emrouznejad A., Cabanda E. (eds) Managing Service Productivity. International Series in Operations Research \& Management Science, vol 215. Springer, Berlin, Heidelberg

Kumar, S., Raizada, I, Biswas, H. and Mishra Pk.,2015 Assessing the Impact of Watershed Development on Energy Efficiency in Groundnut Production Using DEA Approach in the Semi-Arid Tropics of Southern India, doi: 10.18520/v109/110/1831-1837, Research Communivations,

Marvinney, E., Kendalj, A., Brodt, S., 2015, Life Cycle-based Assessment of Energy Use and Greenhouse Gas Emissions in Almond Production, Part II: Uncertainty Analysis through Sensitivity Analysis and Scenario Testing, Journal of Industrial Ecology, P:10191029, DOI:10.1111/jiec.12333

Mousavi-Avval, S., H., Rafiee, S., Jafari, A., and Mohammadi, A., 2011. Energy flow modeling and sensitivity analysis of inputs for canola production in İran. Journal of Cleaner Production,19(2011)-1464-1470, (www.elsevier.com/locate/biombioe, USA).

Mrini, M., F. Senhaji, D. Pimentel. 2002. Energy analysis of sugar beet production under traditional and intensive farming systems and impacts on sustainable agriculture in Morocco. Research, Reviews, Practices, Policy and Technology, Journal of Sustainable Agriculture, 20(4): 5-28

Nabavi-Pelesaraei,A, Abdi, R, Rafiee, S., 2013, Energy use pattern and sensitivity analysis of energy inputs and economical models for peanut production in Iran, International Journal of Agriculture and Crop Sciences. Available online at www.ijagcs.com IJACS/2013/5-19/2193-2202 ISSN 2227-670X @2013 IJACS Journal.

Öztürk, H. H., 2011. Bitkisel Üretimde Enerji Yönetimi. Hasad yayıncılık. 2011.

Sabah, M., 2010. Söke Ovasında İkinci Ürün Yağlık Ayçiçeği Üretiminde Enerji Kullanımı. Çukurova Üniversitesi Fen Bilimleri Enstitüsü Tarım Makinaları Anabilim Dalı. Yüksek Lisans Tezi. Adana.

Singh, M.K., Pal, S.K., Thakur, R, Verma, U.N, 1997. Energy input-output relationship of cropping systems, Indian Journal of Agricultural Sciences 67 (6) : 262-4, June 1997

Umar, B., 2003 "Comparison of Manual and Manual-cum-Mechanical Energy Uses in Groundnut Production in a Semi-arid Environment". Agricultural Engineering International: the CIGR Journal of Scientific Research and Development. Manuscript EE 03 003. May, 2003

Yılmaz, İ, A. Özalp ve F. Aydoğmuş, 2010. Antalya ili bodur elma üretiminde enerji kullanım etkinliğinin belirlenmesi: Elmalı ilçesi örneği. Akdeniz Üniversitesi Ziraat Fakültesi Dergisi 23(2): 93-97 